SOSYAL BILGILER DERSI 5. SINIF “iLKÇAĞ UYGARLIKLARI” KONULARININ ÖĞRETIMINDE HIKÂYE DESTEKLi ÖĞRETiM YÖNTEMININ ETKILILiĞi ${ }^{1}$

The EFFECTIVENESS of STORY-BASED TEACHING METHOD in TEACHING of "ANCIENT CIVILIZATIONS" in $5^{\text {TH }}$ GRADE SOCIAL STUDIES COURSE

\title{
Fadime SEÇGIN
}

Tokat Gaziosmanpaşa Üniversitesi, Eğitim Fakültesi, E-posta: fadime.secgin@gop.edu.tr orcid.org/0000-0001-6461-8764

\section{Mustafa DOĞAN}

Milli Eğitim Bakanlığı, E-posta: ahdaram@gmail.com orcid.org/0000-0002-9591-9735

Article Info

\begin{tabular}{|c|c|}
\hline Article Type & Research \& Theoretical \\
\hline Received & 26.03.2019 \\
\hline Accepted & 16.05 .2019 \\
\hline DOI & 10.17497/tuhed.544746 \\
\hline Corresponding Author & Fadime SEÇGIN \\
\hline Cite & $\begin{array}{l}\text { Seçgin, F. ve Doğan, M. (2019). Sosyal bilgiler dersi 5. sınıf "ilkçağ } \\
\text { uygarlıkları" konularının öğretiminde hikâye destekli öğretim } \\
\text { yönteminin etkililiği. Turkish History Education Journal, 8(1), ss. } \\
\text { 290-316. doi: 10.17497/tuhed.544746 }\end{array}$ \\
\hline
\end{tabular}

${ }^{1}$ Bu çalışma ikinci yazarın birinci yazar danışmanlığında yürüttüğü yüksek lisans tezinin bir bölümüdür. 
Öz: Bu araştırmanın amacı sosyal bilgiler dersi 5. sınıf 'ilkçağ uygarlıkları' konularının öğretiminde hikâye destekli öğretimin öğrencilerin akademik başarılarına ve farkındalık düzeylerine etkisini ortaya koymaktır. Araştırma nicel araştırma modellerinden deneysel desende gerçekleştirilmiş; hikâye destekli öğretimin uygulandığı deney grubu ile hikâye destekli öğretimin uygulanmadığı kontrol grubunun başarıları arasındaki farkı ortaya koymak amacıyla "öntest-sontest deney-kontrol gruplu yarı deneysel desen" kullanılmıştır. Elde edilen sonuçları desteklemek için ise nitel araştırma modellerinden olgubilimden yararlanılmış ve öğrenci görüşlerine başvurulmuştur. Araştırmanın çalışma grubunu Malatya Battalgazi ilçesindeki bir okulda yer alan $5 / B$ ve $5 / C$ sınıflarında her birinde 33'er öğrencinin yer aldığı 66 öğrenci oluşturmaktadır. Veri toplama araçları olarak nicel verilerin toplanmasında araştırmacılar tarafından hazırlanan ilkçağ uygarlıklarına ait başarı testi ve nitel verilerin toplanması sürecinde de her bir uygarlığa ait çalışma yapraklarından ve öğrenci mülakatlarından yararlanılmıştır. Uygulama sürecinde 5. Sınıf öğretim programında yer alan "Kültür ve Miras" ünitesi konularından olan "ilkçağ Uygarlıkları"yla ilgili sekiz adet hikâye tasarlanmıştır. Ortaya çıkan sonuçlara göre hikâye destekli öğretim yönteminin uygulandığı deney grubu başarı ortalamasının, geleneksel öğretim yöntemlerinin uygulandığı kontrol grubunun başarı ortalamasından daha yüksek olduğu görülmüştür. Bununla birlikte elde edilen nitel bulgular, öğrencilerin ilkçağ uygarlıkları ile ilgili farkındalık kazanabildiklerini; farklı kültürden insanlar arasındaki fakları kavrayarak empati kurabildiklerini göstermektedir.

Anahtar Kelimeler: Hikâye, Sosyal Bilgiler, Illkçağ Uygarlıkları

\begin{abstract}
The purpose of this study is to reveal the effect of story-based teaching on students' academic achievement and awareness levels in teaching the subjects of "Ancient Civilizations" in $5^{\text {th }}$ grade social studies course. The study was carried out in experimental design from quantitative research models. "the pretest-posttest experimental-control group which is a quasi-experimental" was used in order to reveal the difference between the success of the experimental group in which the story-based teaching method is applied and the control group in which the story-based teaching method is not applied. In order to support the results, phenomenology, one of the qualitative research models, was used and students' opinions were considered in the study. The study group consists of 66 students in 5/B (33 students) and 5/C (33 students) classes in a school in Battal Gazi district of Malatya. As data collection tools, achievement test of ancient civilizations prepared by researchers is used in the collection of quantitative data while the worksheets and student interviews of each civilization is used in the process of collecting qualitative data. In the application process, eight stories about "Ancient Civilizations" which is one of the topics of "Culture and Heritage" unit in the curriculum of the 5th grade are designed. According to the results, it was observed that the mean success of the experimental group in which the story-based teaching method is applied is higher than the control group in which the traditional teaching methods are applied. However, the qualitative findings show that students can gain awareness about the ancient civilizations and they can show empathy by understanding the differences between people of different cultures
\end{abstract}

Keywords: Story, Social Studies, Ancient Civilizations 


\section{Extended Summary}

\section{Purpose}

The purpose of this study is to reveal the effect of story-based teaching on students' academic achievement and awareness levels in teaching the subjects of 'Ancient Civilizations' in $5^{\text {th }}$ gardesocial studies course. For this purpose, it was remarked that the stories were designed within the scope of the study, they were suitable to historical reality, the factors (elements) such as names, places, spaces, cities, rivers, mountains, gods, things, and person names were used the names of those periods for and reflect the emotions, thoughts and movements of the period was reflected as much as possible.

In this context, the following sub-problems were sought:

- Do the achievement scores of the experimental group in which The story is used as teaching materials and the control group in which The test-book is used as teaching materials differentiate according to groups (experimental- control), measurements (pretest -posttest) and their common effect?

- What are the changes in the awareness level about civilizations in the minds of students as a result of the story-based practices?

\section{Method}

The study was carried out in experimental design from quantitative research models. "the pretest-posttest experimental-control group which is a quasi-experimental" was used in order to reveal the difference between the success of the experimental group in which the story-based teaching method is applied and the control group in which the story-based teaching method is not applied. In order to support the results, phenomenology, one of the qualitative research models, was used and students' opinions were considered in the study.

The study group consisted of 66 students in 5/B (33 students) and 5/C ( 33 students) classes in a school in Battal Gazi district of Malatya. As data collection tools, achievement test of ancient civilizations prepared by researchers is used in the collection of quantitative data while the worksheets and student interviews of each civilization is used in the process of collecting qualitative data. In the application process, eight stories about "Ancient 
Civilizations" which is one of the topics of "Culture and Heritage" unit in the curriculum of the 5 th grade were designed. They are the stories of "the Sumerian Sun" related to Sumerian civilization, "Assyrian Traders" in the Assyrian Civilization, "Hanging Gardens of Babylon" with regard to the Babylonian Civilization, "Hittite country" regarding Hittite Civilization, 'Phrygian King Gordio's on Phrygian Civilization, "Gold Country Lydia" regarding Lydia civilisation, Ionian Cities related to Ionian Civilization and "Urartu with High Mountains" for Urartian civilization in the textbook.

In the control group 5/B class, the subjects of Ancient Civilizations were thought through the textbook in accordance with the 5 th grade social studies program. For each story read in the experimental group, story texts were distributed to each of the students, general information were given about the relevant civilization and the relationship between story and civilization were explained. By asking to the students' thoughts about the stories, the worksheets were distributed to learn their thoughts and awareness about the story at the end of the course. Each of these work sheets includes 4 questions.

As a result of the application process, the "Ancient Civilizations Achievement Test", which consists of the same questions to the experimental and control groups, was conducted as a post-test. The results were evaluated statistically and certain recommendations were made according to the results.

\section{Results and Discussion}

The results of the study revealed that the story-based teaching method increased the student success. That the post-test achievement score of the experimental group was higher than the post-test achievement score of the control group showed that story-based teaching had a positive effect on students' academic achievement. These results were similar to the results of some studies on the efficiency of teaching methods using literary products Akengin and Tuncel, 2003; Demir, 2011; Keskin, 2008; Sidekli, Tangülü and Yangın, 2013; Şimşek, 2000; Şimşek, 2004).

During the applications, it was observed that the historical information expressed in literary language was followed with interest by the students, and they followed the characters in the stories with interest and great curiosity. It was observed that students who had difficulty in grasping information such as war, peace, agreement followed the fictional narrative in the 
stories with a greater interest and concern. These results showed similarities with the studies conducted by Ata, 2014; Akkuş, 2007; Demir and Akengin, 2012; Dilek and SoğucaklıYapıcı, 2005; Kaymakçı, 2013; Oruç, 2009; Öztürk and Otluoğlu, 2002; Öztürk i. H, 2011; Öztürk, Keskin and Otluoğlu, 2014; Şimşek, 2014 in the literature.

\section{Conclusion}

As a result; it was concluded that group students in the experimental group where the story-based teaching method was applied have a better understanding of the gains; they could express the characteristics of the civilizations described in the stories better.

According to the results of this study, it was observed that the story-based teaching method increased the student success. When the discussions in the classroom and outcomes at the end of process were evaluated, it was found that permanent and meaningful designs of civilizations developed in students' minds and the historical information was followed with interest by students during the study process.

Based on the results of the research, the following recommendations can be made:

- In the teaching of social studies course, different stories can be used in accordance with the content of other units.

- In order to ensure the active participation of the students in the lesson, the students may be asked to write the stories appropriate to the content of the units by using their own creativity.

\section{Giriş}

Sosyal bilgilerin soyut ve birbirinden kopuk konulardan oluştuğu, öğrencilerin bu konular arasında bağlantı kurmakta zorlandığı ve sonuç olarak ezbere dayalı bir anlayışın öğrenciye dayatıldığı şeklinde yorumlanabilecek bir dizi eleştirinin sonucunda sosyal bilgiler öğretiminde farklı yaklaşımlar arayışına girilmiştir. Sosyal bilgiler reformcuları çeşitli öğretim stratejileriyle zenginleştirilmiş edebiyat temelli öğretim anlayışıyla tarih, coğrafya ve diğer sosyal bilimlerin içerik temeline oturtulmuş, daha sevimli bir sosyal bilgilerin oluşturulmaya 
başlanacağını ileri sürmüşlerdir (Mcgown ve Guzetti, 2004). Özellikle sosyal bilgiler dersinde yer alan tarih konularının öğretiminde, öğretmen merkezli yaklaşımdan ziyade öğrenci merkezli yöntem ve etkinliklerin kullanılmasının daha doğru olacağı vurgulanmaktadır (Köstüklü, 2006, s. 35). Bu anlamda sosyal bilgiler programında yer alan kazanımların öğrencilere aktarılabilmesi için, çocukların okurken ya da dinlerken keyif alabilecekleri edebiyat ürünlerinin kullanılabileceği söylenebilir. Edebi ürünler kurgu ve gerçeği birleştiren yapısı gereği okuyanlardan merak, ilgi, heyecan, korku, endişe, hüzün gibi pek çok insani duygunun oluşmasına imkan sağlayabilirken, insan yaşamına ait durumları düşsel bir anlatı olarak sunabilmektedir. Bu yönüyle edebi ürünlerin sahip olduğu kurgusal anlatı özelliğinin, sosyal bilgiler öğretim programında yer alan kazanımların kalıcı ve etkili bir şekide öğrencilere aktarılmasına imkan sağlayacağı düşünülebilir (Şimşek, 2009, s. 391). Çünkü yazılı ve sözlü edebiyat, sosyal bilgiler derslerine zengin bir materyal olanağı sunmaktadır (Öztürk, Keskin ve Otluoğlu, 2014, s. 41). 2018 yılında yayınlanan revize edilmiş Sosyal Bilgiler Öğretim Programında da, "Efsane, destan, masal, atasözü, halk hikâyesi, türkü ve şiir gibi türlerden yararlanılarak sosyal bilgiler dersi edebî ürünlerle desteklenmelidir. “Öğrenciler, konuları sevdirecek roman, tarihî roman, hikâye, hatıra, gezi yazısı ve fıkra gibi edebî ürünler okumaya teşvik edilmelidir" (MEB, 2018, s. 9) şeklinde ders içeriğinin öğrenilebilmesi ve öğrenciler üzerinde kalıcı öğrenme değişikliği sağlayabilmesi için kullanılacak alternatif yöntemlerden olan edebi türlere atıfta bulunulmuştur.

Alan yazında da yer alan birçok çalışma, sosyal bilgiler ve tarih derslerinde edebi ürünlerin kullanılmasının öğrenci üzerinde olumlu etkisini ortaya koymuştur. Örneğin, Jordan (1992), edebiyat temelli öğretimin tarih öğretimi üzerindeki etkisini belirlemek için yaptığı araştırmada, edebiyat temelli öğretimin tarih derslerinde kullanımının öğrencilerin derslere karşı olumlu tutum ve davranışlar geliştirmesini sağladığını gözlemlemiştir. Savage ve Svage (1993), hikayelerin sosyal bilgiler derslerinde kullanılmasıyla, öğrencilerin farklı kültürden insanlar arasındaki fakları kavrayarak empati kurmalarının mümkün olabileceğini vurgulamıştır. Şimşek (2000), sosyal bilgiler dersi tarih konularının öğretiminde hikaye anlatım yöntemi ve düz anlatım yönteminin öğrenci erişilerine etkisini araştırdığı çalışmasında, hikaye anlatım yönteminin kullanılmasının öğrencilerin üzerinde olumlu etkiye sahip olduğu sonucuna varmıştır. 
Ata (2001), "Çanakale Savaşlarını Nasıl Öğreteceğiz?" adlı makalesinde sosyal bilgiler öğretiminde şiirlerin kullanılması ile ilgili bir araştırma yapmıştır. Bu araştırmada şiirlerin derste etkili kullanılmasının sadece Türkçe dersine bırakılmamasını vurgulamış; sosyal bilgiler ve tarih öğretmenlerinin de derslerinde öğrencilerin düzeyine uygun yazılmış şiirleri kullanması üzerinde durmuştur. Tarih dersi kapsamında savaş meydanını gezerken bir yöntem ya da etkinlik kapsamında şiirleri okuma ya da okutmanın tarih dersi öğretimi ve öğrenimi açısından etkili yöntemlerden biri olduğunu vurgulamıştır. Çençen ve Berk (2014), Ortaöğretim TC İnkılâp Tarihi ve Atatürkçülük Dersinde şiir kullanımına ilişkin öğretmen görüşlerini belirlemeye çalıştıkları çalışmada, Tarih ve TC Inkılâp Tarihi ve Atatürkçülük Dersinin öğretiminde duyuşsal alan kazanımlarına uygun olarak lirik ve epik şiirlerin öğretim materyali olarak kullanılabilir olduğunu; bu şiirlerin acı, özlem, yiğitlik, savaş temaları gibi konuları işlediğinden doğrudan TC İnkılâp Tarihi ve Atatürkçülük dersinin duyuşsal olan kazanımları ile örtüştüğünü vurgulamıştır.

Akkuş (2007), "Tarih Öğretiminde Edebi Ürünlerin Kullanımının Öğrenci Başarısına Etkisi" konulu doktora tezinde, tarih derslerinde edebi ürün kullanımının öğrenci başarısı üzerindeki etkisini araştırmış; edebi ürünlerle desteklenen öğretim uygulamaları sonucunda elde edilen öğrenci başarısının, merkezinde öğretmenin ve düz anlatım yönteminin yer aldığı geleneksel yaklaşımla elde edilen öğrenci başarısından daha yüksek olduğu bulunmuştur. Demir (2011), "Sosyal Bilgiler Öğretim Programına Göre Tasarlanmış Hikâyelerin Etkililiği" konulu doktora tezinde sosyal bilgiler öğretim programıyla bağlantılı olarak tasarlanan hikâyelerin, öğrencilerin tarihi olaylara ilgi ve merakını artırdığı; kronolojik zaman ve mekân algısı kazanarak günümüz olayları ile tarihsel olaylara çoklu bakış açısıyla geniş perspektiften bakabilmeleri ve olaylar hakkında değerlendirme yapabilme becerilerinin kazandırılması sürecinde etkili olduğu sonucuna ulaşılmıştır. Akdağ (2016), hikâye(lerin)nin eğitim-öğretim faaliyetlerinin içerisinde yer almasıyla beraber, küçük yaşlardan itibaren hikâyeler ile karşılaşan ve bu hikâyelerin verdiği mesajlarla büyüyen çocuğun ya da en genel manada bireyin içinde yaşadığı toplumda iletişiminin kuvvetleneceğinive bu sayede sosyalleşeceğini vurgulamaktadır. Dolmaz (2017), sosyal bilgiler öğretiminde tarihsel roman kullanımının yaratıcı yazma becerilerine etkisini araştırdığı çalışmasında, farklı kurgu biçimlerine sahip tarihsel romanların öğrencilerin yaratıcı yazma becerilerini farklı düzeyde geliştirdiği görülmüştür. Yasa ve Pamuk (2017), Türk denizcilik tarihinin öğretiminde tarihsel romanların 
kullanımının tarihsel düşünme becerisine etkisiniinceledikleriaraştırmadaöğrencilerin çalışma sırasındayapmış oldukları etkinlikler aracılığıyla tarihsel kavrama ile tarihsel analiz ve yorumbecerilerini geliştirdiklerini gözlemlemiştir.

Yazılı Edebiyat Ürünlerinden Hikâyelerin Sosyal Bilgiler Öğretiminde Bir Öğretim Materyali Olarak Kullanılması ve Faydaları

Sosyal bilgiler dersinde yaralanılabilecek edebi ürünlerden biri de kısa hikâyelerdir (Öztürk ve Otluoğlu, 2003, s. 101). Sosyal Bilgiler Öğretim Programı'nda var olan kazanımlarla bağlantılı hikâyeler öğrencilerin derse yönelik tutum ve ilgilerini değiştirebilir (Otluoğlu, 2001, s. 73; Gilding, 1997, s. 26; Jordon, 1992, s. 20). McEwan ve Egan, (1995, s. 202) amaca hizmet eden hikâyelerin, öğrencilerin akademik başarıları ve öğrenmeleri üzerinde de etkili olduğunu vurgular. Hikâyelerin sosyal bilgiler öğretiminde kullanılması aynı zamanda öğrencilerin, kültürel farklııkları anlamalarına yardım eder; öğrencilere hikâyede yer alan karakterler kadar, yerler hakkında da düş gücü sunar ve 'sonra' ve 'şimdi' kavramları kadar, 'değişim' ve 'süreklilik' kavramlarını da geliştirir (Savage ve Savage, 1993, s.36). Özellikle tarihi hikâyeler, geçmiş toplumların serüvenlerini, hatıralarını anılarını ve başlarından geçen önemli olsun veya olmasın pek çok olayı konu alan anlatılardır. Insanlık tarihi boyunca geçmiş dönem hikâyelerinin sürekli olarak rağbet görmesinin en önemli nedenini, insanın kendi serüvenini, kendini anlama fırsat ve imkânlarını bu hikâyelerde bulabilmesi olarak ifade etmek mümkündür (Köksal, 2007). Hikâyelerin tarihi bilgilerin öğretiminde kullanılması, anlatılan döneme ait düşünce tarzının ve bakış açılarının yansıtılabilmesine, öğrencilerin kahramanlarla empati kurmasına imkân sağlayabilir.

\section{5. sınıf Sosyal Bilgiler Dersi ve İlkçağ Uygarlıkları}

Tarih öğretimi, tarih yazımından hareketle, tarihsel sürecin daha kolay anlaşılabilmesi için onu zamansal bölümlere (çağlara) ayırmıştır (Şimşek, 2011, s. 921). Yazının icadı ile başlayan dönem olarak öne çıkan 'ilkçağ Uygarlıkları' konuları, tarih ve sosyal bilgiler derslerinde önemli bir yere sahiptir. 'Eskiçağ Tarihi' veya 'ilkçağ Uygarlıkları' tarihi olarak ifade edilecek öğrenme alanıyla, yazının icadı ile başlayan tarih çağlarının kronolojik bir bütünsellik içerisinde öğrenilebilmesi hedeflenmektedir. Tarih bilincinin oluşabilmesi, tarih konularının bir bütünlük içerisinde ele alınması ile mümkün olabilir. Burada öğrencilerin geçmiş toplumların yaşam pratiğini öğrenmeleri günümüz dünyasını öğrenmeleri açısından ciddi katkılar 
sunacaktır (Yılmaz, 2011, s. 2149). Bu bağlamda 'Eskiçağ Tarihi' ve 'ilkçağ Uygarlıkları' tarihinin bütüncül bir tarih algısının oluşumunda önemli bir başlangıç basamağı olduğu görülmektedir (Öztaşkın ve Üngör, 2013, s. 2,3). İlkçağ uygarlıklarına ait bilgilerin metinsel anlatı olarak sunulması, öğrencilerin tarihi bilgileri soyut bir yaşantı olarak değerlendirip yeteri kadar öğrenememelerine neden olabilmektedir. Bu nedenle özellikle sosyal bilgiler ve tarih dersleriyle alakalı kitaplarda yer alan konuların öğrenciler açısından daha eğlenceli hale getirilebilmesi için hikâye, tarihi romanlar, şiir,...vb gibi edebi ürünlerden yararlanılabilir (Taşkın, 2016, s. 71).

Illkçağ Uygarlıkları 5. sınıf sosyal bilgiler ders kitabında "Kültür ve Miras" ünitesi içerisinde yer almaktadır. Ders kitabında uygarlıklar kendi isimleri ifade edilen başlıklar halinde sıralanmış olup, kısa bir paragraf halinde açıklayıcı bilgiler verilmiştir. Genel olarak konuların soyut ve metne bağlı olması nedeniyle ilkçağ uygarlıkları konularının öğretiminde ezbere dayalı öğrenmelerin öne çıkabileceği düşünülmektedir. Sosyal bilgiler öğretim programında 5. sınıf sosyal bilgiler programında yer alan "Kültür ve Miras" ünitesinin "Uygarlıkları Öğreniyorum" öğrenme alanıyla ilgili hedef kazanımları: "Somut kalıntılarından yola çıkarak Anadolu ve Mezopotamya uygarlıklarının insanlık tarihine önemli katkılarını fark eder" (MEB, 2018, s. 15), olarak ifade edilmiştir. 'Uygarlıkları Öğreniyorum' öğrenme alanı kapsamında yer alan başlıca İlkçağ Uygarlıkları Anadolu Uygarlıkları ve Mezopotamya Uygarlıkları olmak üzere iki başlık halinde ele alınmıştır. Anadolu Uygarlıkları, Hititler, Frigler, Lidyalılar, Urartular, İyonlar ve Mezopotamya Uygarlıkları ise Sümerler, Asurlar ve Babiller şeklinde yer almaktadır. Sosyal bilgiler ders kitaplarından ilkçağ uygarlıklarına ait özelliklerin; kurulduğu yer, başkent, ekonomi, önemli liderler ve dönemin önemli eserleri gibi birkaç temel bilgi ile ifade edildiği görülmektedir. Bu durum bilginin ezberlenmesine ve bu nedenle kısa sürede unutulmasına neden olabilir. Bu nedenle sosyal bilgiler dersinde, tarih konularının kalıcı ve etkili bir şekilde hikâyeler gibi alternatif yöntemlerle verilmesinin etkili ve kalıcı öğrenmeler sağlaması beklenebilir. Özellikle ilkçağ uygarlıkları ile ilgili tasarlanan hikâyelerin, dönemin yaşam tarzını, sosyal ilişkilerini, ekonomik ve ticari faaliyetlerini, siyasi ve askeri süreçlerini kalıcı ve etkili bir şekilde sunabileceği ve öğrenmelerin daha kalıcı olabileceği düşünülmektedir. Ifade edilen gerekçelerle gerçekleştirilmiş olunan bu araştırmada ise 5. sınıf sosyal bilgiler dersindeki 'Kültür ve Miras Ünitesi'nde yer alan "Uygarlıkları Öğreniyorum” konusu içerisinde "ilkçağ Uygarlıkları" ile ilgili kazanımların hikâyeler yoluyla kazandırılması amaçlanmış olup, bu 
doğrultuda tasarlanan hikâyelerin öğrenci başarısına etki düzeyi ve öğrencilerin ilkçağ uygarlıklarına ilişkin farkındalık durumu belirlenmeye çalışımıştır. Bu nedenle araştırma kapsamında tasarlanan hikâyelerin anakronik bir açmaza düşmemesi için tarihsel gerçekliğe uygun olmasına, yer, mekân, şehir, ırmak, dağ, tanrı, eşya ve kişi isimleri gibi durumlar için o döneme ait isimlerin kullanılmasına, döneme ait duygu, düşünce ve hareket şeklini olabildiğince yansıtabilmesine dikkat edilmiştir. Bununla birlikte bilinmeyen kelimeler, yer isimleri ve gerekli açıklamalar sıklıkla yapılmıştır.

Bu çerçevede aşağıdaki alt problemlere yanıt aranmıştır:

- Hikâyelerin öğretim materyali olarak kullanıldığı deney ve ders kitabının öğretim materyali olarak kullanıldığı kontrol gruplarının başarı puanları gruplara (deney kontrol), ölçümlere (öntest-sontest) ve bunların ortak etkisine göre farklılaşmakta mıdır?

- Hikâye destekli uygulamalar sonucunda öğrencilerin zihinlerinde uygarlıklara ilişkin farkındalık düzeylerindeki değişiklikler nelerdir?

\section{Yöntem}

\section{Araştırmanın Modeli}

Bu araştırmada nicel araştırma modellerinden hikâye destekli öğretimin uygulandığı deney grubu ile hikâye destekli öğretimin uygulanmadığı kontrol grubunun başarıları arasındaki farkı ortaya koymak amacıyla "öntest-sontest deney-kontrol gruplu yarı deneysel desen" kullanılmıştır. Elde edilen sonuçları desteklemek için ise nitel araştırma modellerinden olgubilimden (fenomenoloji) yararlanılmış ve öğrenci görüşlerine başvurulmuştur. Deneysel desenler, neden sonuç ilişkilerini belirlemeye çalışmak amacı ile doğrudan araştırmacının kontrolü altında, gözlenmek istenen verilerin üretildiği araştırma desenleridir (Karasar, 2002). Yarı deneysel desen de deneysel desenle aynı amacı taşımaktadır. Aralarındaki farklılık, yarı deneysel desende, kontrol ve deney gruplarının tesadüfen değil ölçümlerle seçilmesidir (Karasar, 2002). Olgubilim deseni ise "farkında olduğumuz ancak derinlemesine ve ayrıntılı bir anlayışa sahip olmadığımız olgulara odaklanmaktadır” (Yıldırım ve Şimşek, 2005). 
Uygulama için deney ve kontrol grupları seçilirken sınıfların mevcudu, hazır bulunuşluk düzeyleri, sosyal bilgiler dersi için genel akademik başarıları dikkate alınmıştır. Deney ve kontrol gruplarının denkliğini belirlemek için her iki gruba da öntest verilmiştir.

Aşağıda Tablo 1'de öntest-sontest deney-kontrol gruplu yarı deneysel desen sembolize edilmiştir.

Tablo 1

Öntest-Sontest Deney- Kontrol Gruplu Yarı Deneysel Desen

\begin{tabular}{cccc}
\hline Gruplar & Öntest & İşlem & Sontest \\
\hline Deney (5/C Sınıfı) & Başarı Testi & Hikâye Destekli Yapılan Öğretim & Başarı Testi \\
Kontrol (5/B Sınıfı) & Başarı Testi & Ders Kitabı ile Yapılan Öğretim & Başarı Testi \\
\hline
\end{tabular}

\section{Çalışma Grubu}

Bu araştırmanın ulaşılabilir evrenini 2018-2019 eğitim öğretim yılında Malatya ili Battalgazi İlçesinde Millî Eğitim Bakanlığı'na bağlı bir okulda öğrenim gören 5. sınıf öğrencileri oluşturmaktadır. Deney ve kontrol gruplarının belirlenmesinde sınıf mevcudu ve başarı düzeyi gibi durumlara dikkat edilerek birbirine yakın iki sınıf seçilmiştir. Bu sınıflardan tesadüfi 5/C sınıfı (N:33) deney grubu olarak belirlenirken; 5/B sınıfı (N:33) kontrol grubu olarak belirlenmiştir.

Öncelikle grupların denk olup olmadığını belirlemek üzere gruplara İlkçağ Uygarlıkları Akademik Başarı Testi uygulanmış ve öntest puan ortalamaları arasında farkın anlamlı olup olmadığı Ilişkisiz Örneklemler t- Testi ile test edilip karşılaştırılmıştır.

Çalışma gruplarının öntest sonuçları için yapılan İlişkisiz Örneklemler t- Testi sonuçları Tablo 2' de verilmiştir.

Tablo 2

Deney ve Kontrol Grubu Öntest Ilişkisiz Örneklemler t- Testi Sonuçları

\begin{tabular}{lllcllll}
\hline İşlem & Grup & $\mathbf{N}$ & $\bar{X}$ & ss & sd & t & p \\
\hline Öntest Başarı & Deney & 33 & 32,84 & 14,16 & 64 &,- 978 &, 33 \\
Puanı & Kontrol & 33 & 36,00 & 11,91 & & & \\
\hline
\end{tabular}

$p>0,05$ 
Tablo 2 incelendiğinde test sonuçlarına göre deney ve kontrol grubunun öntest ortalama puanları arasında istatistiksel olarak anlamlı bir farklılık bulunmamaktadır, $[\mathrm{t}(64)=-$ ,978, p>,05]. Bu bulgu, uygulama öncesinde deney ve kontrol gruplarının ilkçağ uygarlıkları konusuna ait kazanımlar açısından akademik başarıları arasında anlamlı bir fark olmadığını belirlemiştir.

Ardından uygulamalar için gerekli izinler alınarak ders içi etkinlikler planlanmış ve uygulamalar yapılmıştır. Sınıf mevcudunun yeterli olması nedeniyle odak öğrenciler yerine sınıfta yer alan öğrencilerin tamamı ile çalışılmıştır. Nitel verilerin toplanması için kullanılan öğrenci çalışma kâğıtlarında ve öğrenci mülakatlarında araştırmaya katılan öğrencilerin her biri 'katılımcı' olarak adlandırı Imıs ve ' $\mathrm{K}$ ' harfi ile gösterilmiştir. Her öğrenci için sıra numarası verilmiştir.

\section{Veri Toplama Araçları}

Bu bölümde nicel ve nitel veri toplama araçları açıklanmıştır.

\section{Nicel Veri Toplama Araçları}

Araştırmada başarı testi uygulanmıştır. Başarı testi, bir konunun veya ünitenin öğrenilmesiyle kazanılan yeterliliklerin ortaya çıkarılması amacıyla hazırlanan bir sınav aracıdır (Turgut, 1992, s. 4). Bu araştırmada 5. Sınıf Sosyal Bilgiler Dersi Programı́nda yer alan İlkçağ Uygarlıkları ile ilgili olarak tasarlanan hikâyelerin öğrencilerin akademik başarısına olan etkisini ölçmek hedeflenmektedir. Bu amaçla öğrenci başarını ölçebilmek amacıyla başarı testi geliştirilmiş olup, testin geçerlilik ve güvenirlilik analizi yapılmıştır. Uygulama öncesinde deney ve kontrol grubuna uygulanan test uygulamadan sonra tekrar deney grubuna uygulanmıştır. Elde edilen veriler, uygulama öncesinde uygulanan öntest ve uygulama sonrasında aynı testin sontest olarak tekrar uygulanması sonucunda elde edilmiştir. Öntest ve sontest sonuçları arasındaki veriler $t$ testi ile gösterilmiş ve sonuçlar yorumlanmıştır.

\section{Başarı Testinin Geliştirilme Aşamaları}

5. Sınıf Sosyal bilgiler "Kültür ve Miras" ünitesinde yer alan "ilkçağ Uygarlıkları" konularının analizi yapılmıştır. İlkçağ Uygarlıkları olarak 5. Sınıf Sosyal Bilgiler programında yer alan Sümer, Asur, Babil, Hitit, Frig, Lidya, Urartu ve İyon uygarlıkları ilgili hedef ve kazanımları ölçecek toplam 35 sorudan oluşan başarı testi hazırlanmıştır. Bu testlerin geçerlilik ve güvenirlik analizleri için farklı bir okulda daha önce "ilkçağ Uygarlıkları" konularının işlendiği 
ve bu konulara ait kazanımları elde ettiği varsayılan toplam 100, 5. sınıf öğrencisine ön uygulama yapılmıştır. Araştırmanın yapılacağı deney ve kontrol gruplarında ise daha önce bu konu işlenmemiştir.

Her maddenin Güçlük derecesi (Pj), Standart Sapması (Sj), Ayırıcılık Derecesi (rjx), altüst \%27'lik gruplar için bağımsız gruplar t testi değerleri hesaplanmıştır. Ayırıcılık gücü (rjx) 0.20 'nin altında kalan sorular testten çıkarılmıştır. Elde edilen verilere yapılan geçerlilik ve güvenirlik analizlerinden sonra geçerliği ve güvenirliliği düşük, dil ve anlatım bakımından yeterli görülmeyen 10 soru elenmiş ve çoktan seçmeli ( 3 çeldirici 1 cevap) 25 soru kalmıştır.

Ön test ve son test olarak öğrencilere verilen başarı testindeki her bir soru 4 puan belirlenmiş olup test 100 üzerinden değerlendirilmiştir. Bu nedenle öğrencilere uygulanan başarı testinde sonuçların 0 ila 100 arasında değişmesi beklenmektedir.

Tablo 3.

Test Analiz Tablosu

\begin{tabular}{ll}
\hline & Test Analiz Verileri \\
\hline Madde Güçlüğü & 0,725 \\
Ayırt Edicilik & 0,317 \\
KR20 ( Alpha) & 0,771 \\
KR21 & 0,742 \\
Standart Sapma & 4,158 \\
Varyans & 17,293 \\
\hline
\end{tabular}

Sınavın güvenilirlik katsayısı 0 ile \pm 1 arasında bir değer almaktadır. Sıfıra yaklaştıkça güvenirliliğinin düşük olduğu, 1'e yaklaştıkça yüksek olduğu beklenmektedir. Hazırlanan testin güvenirliği 0,771 olarak hesaplanmıştır. Bu sonuç, uygulama için yeterligörülmektedir.

\section{Nitel Veri Toplama Araçları}

Nitel verilerin toplanması aşamasında öğrencilerin okudukları hikâyelere dair düşüncelerini, hikâyede yer alan karakterler, zaman dilimi ve mekânla kendi yaşamları arasında özdeşim kurabilme becerilerini ortaya koyabilecek açık uçlu soruların yer aldığı öğrenci çalışma kâğıtlarından yararlanılmıştır. Bu çalışma kağıtlarında örneğin Sümer Güneşi adlı hikaye için "Bir tarihçi olsaydınız Sümerlerin dünya tarihi açısından önemini nasıl ifade ederdiniz?, hikâyenin çocuk kahramanı Abebe'nin yerinde olsaydınız, neler hissederdiniz?," Asur Tüccarları adlı hikaye için "Hikâyenin kahramanları olan Hanu ve Yakmesi gibi uzun bir ticaret yolculuğuna çıktığınızı düşünün ve bu yolculuğa dair hayallerinizi yazınız?, Hanu ve 
Yakmesi'nin yolları üzerinde bulunan Melid (Malatya) krallığını ve Kral Hilaruda'nın saray odasını kendi hayal dünyanızda canlandırın ve yazınız?" Babil'in Asma Bahçeleri adlı hikâye için “Okuduğunuz hikâyedeki Babil şehriyle yaşadığınız şehri karşılaştırınız? Babil şehrinde yaşayan bir mimar olsaydınız, binaların üzerinde bahçe yapabilmek için ve bütün bir şehri yeşillendirebilmek için nasıl bir yol izlerdiniz?" gibi her bir hikâye için 4'er soru yer almaktadır. Ve her bir hikâyeye ait çalışma yapraklarında ortak olarak "Okuduğunuz hikâyenin kalıcı ve anlamlı bir şekilde öğrenmenize yardımcı olduğunu düşünüyor musunuz?" sorusu sorulmuştur.

\section{Hikâyelerin Tasarlanması}

5. Sınıf öğretim programında yer alan "Kültür ve Miras" ünitesi konularından olan "Uygarlıkları Öğreniyorum" öğrenme alanına yönelik ilkçağ uygarlıklarıyla alakalı araştırmacılar tarafından sekiz adet hikâye yazıımıştır. Ders kitabında yer alan Sümer Uygarlığı ile ilgili olarak "Sümer Güneşi”, Asur Uygarlığı ile ilgili olarak "Asur Tüccarları", Babil Uygarlığı ile ilgili olarak, "Babil'in Asma Bahçeleri", Hitit Uygarlığı ile ilgili olarak "Hitit Ülkesi", Frig Uygarlığı ile ilgili olarak “Frigya Kralı Gordios”, Lidya Uygarlığı ile ilgili olarak "Altın Ülke Lidya”, İyon Uygarlığı ile ilgili olarak "lyonya Şehirleri” ve Urartu Uygarlığı ile ilgili olarak ise "Yüksek Dağlar Ülkesi Urartu” isimli hikâyeler tasarlanmıştır. Babil Uygarlığının anlatıldığı 'Babil'in Asma Bahçeleri' adlı hikâye Babil Kraliçesi Semiramis'in hikâyesinden yola çıkılarak araştırmacı tarafından tekrar uyarlanmıştır. Frig uygarlığının anlatıldığı 'Frig Kralı Gordios' hikâyesinde 'Gordion Düğümü' ile ilgili anlatıdan yola çıkılarak yeni bir hikâye tasarlanmıştır. Lidya Uygarlığının anlatıldığı 'Altın Ülke Lidya' hikâyesi ise, Lidya Kralı Kroisos ve düşünür Solon arasında geçen tarihi hikâyeden yola çıkılarak yeni bir hikâye olarak tasarlanmıştır.

Tarihsel bilgilerin hikâyede yer alan karakterler aracılığı ile anlatılma aşamasında karşılaşılan en önemli problemlerden birisi kendi dönemimize ait düşünme biçimlerinin, 0 dönemin düşünce unsurlarıymış gibi yansıtılmasıdır (Öztürk, 2011, s. 43). Özellikle yanlış anlaşılmaların olmaması için, hikâyelerin yazılma sürecinde tarihsel gerçekliğe riayet edilmiş, hikâyelerin dönemin sosyal, kültürel, siyasi ve iktisadi yapısına uygun olması için gerçekçi ve hedef kazanımların kurgu içerisine dâhil edildiği bir üslup kullanıımıştır. İlkçağ uygarlıkları ile ilgili olarak araştırmacılar tarafından kaleme alınan hikâyelerde didaktik, öğretici ve belletici üsluptan kaçınılmış, bunun yerine öğrencilerin alternatif bakış açıları geliştirebilmesi ve antik dönem insanı ile duygudaşlık kurabilmesi için, tarihsel bilgiler edebi bir üslupla verilmeye 
çalışılmıştır. Ders verici bir anlatı yerine, hikâyelerde anlatılan medeniyete ait özellikler sosyal yaşamdan örneklerle ifade edilmiştir. Bu sayede tarihsel bilginin öğrenciler tarafından kendi yaşamları ile ilişkilendirilmesi ve tarihsel empati kurabilmeleri beklenmektedir.

\section{Uygulama Süreci}

Araştırma uygulamalarının yapıldığı 5/C sınıfında 14 erkek 19 kız olmak üzere toplam 33 öğrenci bulunurken 5/B sınıfında 13 erkek, 20 kız olmak üzere toplam 33 öğrenci bulunmaktadır. Her iki sınıf da ısı, ışık, ses yalıtımı, oturma düzeni ve temizlik açısından uygunluk arz etmektedir.

Deney ve kontrol gurubunda yapılan uygulamalar araştırmacının kendisi tarafından gerçekleştirilmiş, araştırma süresince sosyal bilgiler dersine araştırmacının kendisi girmiştir. Uygulamalar öncesinde deney ve kontrol gurubunun derslerine giren sosyal bilgiler öğretmeni ile birlikte araştırmacı tarafından öğrencilere yapılacak çalışmalar hakkında bilgi verilmiştir.

Çalışma, sosyal bilgiler dersini işleyen araştırmacı tarafından ders programına uygun olarak; deney grubunda 23.10.2018 tarihinde başlayıp 20.11.2018 tarihinde biterken, kontrol grubunda 26.10.2018 tarihinde başlayıp 21.11.2018 tarihinde bitmiştir. Her iki sınıfta da uygulamalar 5 hafta olarak planlanmış ve uygulanmıştır.

Araştırma sürecinin başında deney ve kontrol gurubuna "ilkçağ Uygarlıkları Başarı Testi" uygulanmıştır. Her iki grubun da birbirine benzer özelliklere sahip olması nedeniyle kontrol grubu olan 5/B sınıfında "Kültür ve Miras Ünitesi" dâhilinde yer alan Illkçağ Uygarlıkları konuları,5. sınıf sosyal bilgiler programına uygun olarak ders kitabının kullanıldığı anlatım yöntemiyle işlenmiştir. Ders öğretmeni olan araştırmacı tarafından "ilkçağ Uygarlıkları" hakkında genel bir bilgi verilmiş ve ardından ders kitabında yer alan uygarlıklar sırasıyla işlenmiştir. Okunan uygarlık hakkında genel bilgiler verildikten sonra ders kitabında yer alan metnin öğrencilerden birisi tarafından okunması sağlanmıştır. Daha sonra önemli olan özellikler ders öğretmeni tarafından tahtaya yazılarak, öğrencilerden yazılanları not alması istenmiştir.

Deney grubu olan 5/C sınıfında ise "Kültür ve Miras Ünitesi"nde yer alan "ilkçağ Uygarlıkları" konularının öğretiminde Edebiyat Temelli Öğretim Yaklaşımı'na uygun olarak her uygarlık için bir hikâye olmak üzere toplam 8 adet hikâye kullanılmıştır. Deney grubunda okunan her hikâye için öğrencilerin her birine hikâye metinleri dağıtılmış ve ilgili uygarlık 
hakkında genel bilgiler verilerek hikâye ve uygarlık arasındaki ilişki açıklanmıştır. Ardından akıllı tahtadan hikâyede anlatılan uygarlığın haritası ve kurulduğu bölgenin yer aldığı haritalar gösterilmiştir. Hikâye metinleri, uygulama sırasında belirlenen beş gönüllü öğrenci tarafından bölümler halinde okunurken, diğer öğrenciler kendilerinde bulunan hikâye kâğıtlarını takip etmişlerdir. Hikâyelerin okunması sırasında önemli görülen bölümlerin üzerinde durularak, ilgili bölümler hakkında tartışmalar yapılmış, öğrencilere ilgili zaman diliminde olmaları durumunda nasıl bir yol izleyecekleri ve olaylara nasıl tepkiler verecekleri sorulmuştur. Hikâyelerde yer alan yaşantılarla kendi yaşantıları arasında yer alan benzerlikleri ifade etmeleri istenmiştir. Ders sonunda okunan hikâyeler hakkında öğrencilere ne düşündükleri sorularak, okuduğu hikâye ile ilgili düşüncelerini yazması içinöğrenciçalışmakâğıtlarıdağıtılmış ve zaman zaman her bir uygarlık için öğrenci mülakatlarına başvurulmuştur.

Uygulama sürecinin sonucunda deney ve kontrol gurubuna aynı sorulardan oluşan “ilkçağ Uygarlıkları Başarı Testi” sontest olarak uygulanmıştır. Elde edilen sonuçlar istatistiksel olarak ele alınmış, ortaya çıkan sonuçlara göre önerilerde bulunulmuştur.

Araştırma sürecinde aşağıdaki adımlar izlenmiştir:

1. Araştırma uygulamalarının yapılabilmesi için İ Milli Eğitim Müdürlüğü ile resmi yazışmalar yapılarak gerekli izinler alınmıştır.

2. Başarı testi geliştirilmiş ve ön uygulama yapılmıştır.

3. Hikâyelerin pilot uygulaması yapılmıştır.

4. Uygulama öncesinde öğrencilere araştırma hakkında bilgi verilmiş, araştırma süreci ayrıntılı bir şekilde açıklanmıştır.

5. Ön test uygulanmıştır.

6. Hikâyeler ders planı doğrultusunda uygulanmıştır.

7. Son test uygulanmıştır.

\section{Verilerin Analizi}

Aşağıda nitel ve nicel verilerin analizine yer verilmiştir.

\section{Nicel Verilerin Analizi}

Öncelikle grupların denk olup olmadığını belirlemek üzere gruplara İlkçağ Uygarlıkları Akademik Başarı Testi uygulanmış ve öntest puan ortalamaları arasında fark olup olmadığı ilişkisiz Örneklemler t- Testi ile test edilip karşılaştırılmıştır. Araştırmada alt problemler 
doğrultusunda kullanılan diğer bir istatistiksel analiz türü ise öntest-sontest kontrol gruplu modellerde grup ve ölçüm temel etkileri ile birlikte grup ve ölçüm ortak etkisini belirlemek üzere gerçekleştirilen karışık ölçümler için İki yönlü ANOVA analizi yapılmıştır (Büyüköztürk, 2007). Araştırmada uygulanan başarı testinden elde edilen verilerin değerlendirilmesinde SPSS paket programından yararlanılmıştır.

\section{Nitel Verilerin Analizi}

Araştırma kapsamında öğrenci çalışma kâğıtlarından ve mülakatlaran elde edilen nitel verilerin çözümlenmesinde betimsel analizden yararlanılmıştır. Betimsel analiz, görüşülen veya gözlenen kişilere ait düşüncelerin doğrudan alıntılar yoluyla verilmesidir. Bu yöntemde temel amaç, elde edilen bulguları düzenlenmesine ve yorumlanarak okuyucuya aktarılması esasına dayanır (Yıldırım ve Şimşek, 2005, s. 224).

\section{Bulgular}

$\mathrm{Bu}$ bölümde öğrencilere uygulanan başarı testlerinden ve çalışma kâğıtları ve mülakatlardan elde edilen bulgular ortaya konulmuştur. Elde edilen veriler yorumlanmış ve araştırma kapsamında sorulan sorulara ayrıntılı bir şekilde cevap verilmiştir.

\section{Birinci Alt Probleme Ait Bulgular}

Araştırmanın birinci alt probleminin analizinde deney ve kontrol grubu öğrencilerinin başarı puanlarının gruplara (deney-kontrol), ölçümlere (öntest-sontest) ve bunların ortak etkisine göre farklılaşıp farklılaşmadığı iki yönlü varyans analiz ile test edilmiş ve sonuçları Tablo 5' de verilmiştir. Öğrencilerin başarı testinden aldıkları öntest - sontest ortalama puan ve standart sapma değerleri ise Tablo 4'de yer almaktadır.

Tablo 4

Öğrencilerin Başarı Testinden Aldıkları Öntest-Sontest Puanlarının Ortalama ve Standart Sapma Değerleri

\begin{tabular}{lcccccl}
\hline & \multicolumn{3}{c}{ Öntest } & \multicolumn{3}{c}{ Sontest } \\
\cline { 2 - 7 } Gruplar & $\mathrm{N}$ & $\bar{X}$ & ss & $\mathrm{N}$ & $\bar{X}$ & ss \\
Deney & 33 & 32,84 & 14,16 & 33 & 73,81 & 11,31 \\
\hline
\end{tabular}




\begin{tabular}{lllllll}
\hline Kontrol & 33 & 36,00 & 11,91 & 33 & 60,24 & 16,52 \\
\hline
\end{tabular}

Araştırmaya katılan öğrencilerin ilkçağ uygarıkklarına ilişkin başarı testinden aldıkları öntest ve sontest puanlarının ortalama ve standart sapma değerleriyle ilgili tablo 5 'de yer alan

bilgilere bakıldığında, deney grubu öğrencilerinin öntest başarı puan ortalamasının $\bar{X}=32,84$ ve sontest başarı puan ortalamasının $\bar{X}=73,81$ olduğu görülmektedir. Kontrol grubu öğrencilerinin ortalama başarı puanları ise öntestte $\bar{X}=36,00$ ve sontestte $\bar{X}=60,24$ olmuştur. Elde edilen bulgulara göre hikâye destekli öğretim yönteminin uygulandığı deney grubu ile ders kitabı ile ders işlenilen kontrol grubu öğrencilerinin başarı düzeylerinde, her iki grubun başarı testine ilişkin ortalamasının da yükselmiş olmasından dolayı, bir artış olduğu ileri sürülebilir.

Tablo 5

Öğrencilerin IIlkçağ Uygarlıkları Başarı Testine Iliş̧kin Öntest ve SontestBaşarı Puanlarının Deney ve Kontrol Grubuna göre Değişimine (Gelişimine) iliş̧kin İki Yönlü ANOVA Sonuçları

\begin{tabular}{lccccc}
\hline Varyansın kaynağı & KT & sd & KO & F & p \\
\hline Gruplararası & 16234,18 & 65 & & & \\
Grup (Deney/Kontrol) & 896,485 & 1 & 896,485 & 3,74 &, 058 \\
Hata & 15337,697 & 64 & 239,652 & & \\
Gruplariçi & 45856 & 66 & & & \\
Ölçüm(Öntest-Sontest) & 35084,121 & 1 & 35084,121 & 265,302 &, 000 \\
Grup*Ölçüm & 2308,364 & 1 & 2308,364 & 17,456 &, 000 \\
Hata & 8463,515 & 64 & 132,242 & 8463,515 & \\
Toplam & 100175,515 & 131 & & & \\
\hline
\end{tabular}

Tablo 5'de öğrencilerin ilkçağ uygarlıkları öntest ve sontest başarı puanlarının iki yönlü ANOVA sonuçları ele alınmıştır. Buna göre; deney ve kontrol grubunda yer alan öğrencilerin öntest ve sontest başarı puanlarının anlamlı farlılık gösterdiği, yani deney ve kontrol gruplarında olmak ile öntest-sontest faktörlerinin başarı üzerindeki ortak etkilerinin anlamlı olduğu bulunmuştur, $[F(1 ; 64)=17,46, p<.05]$. Bu bulgu deney ve kontrol grubundaki bireylerin başarılarındaki değişimin ölçüm ayrımı (deney öncesi ve sonrası) yapmaksızın farkılış̧tığını göstermektedir. Buna göre uygulama öncesi durumları dikkate alındığında deney grubunda yer alan bireylerin başarıları kontrol grubuna göre daha çok artmıştır. Deney ve kontrol grup ayrımı yapmaksızın bireylerin öntest ve sontest puanları toplam puan ortalamaları arasındaki fark da anlamlı bulunmuştur, $[F(1 ; 64)=265,302, p<.05]$. Bununla birlikte deney ve kontrol 
grubunda yer alan bireylerin öntest ve sontest puanlarından elde edilen toplam puanların ortalamaları arasında ise anlamlı bir farklılık bulunamamıştır [F $(1 ; 64), p>.05]$. Ancak bu sonuç grupların öntesttensonteste olan değişimlerini dikkate almamaktadır. Bu bulguya göre hikâye destekli öğretim yöntemi uygulanan deneklerin başarılarında deney öncesine göre gözlenen değişme, kontrol gruplarındaki deneklerin başarılarında gözlenen değişmelerden anlamlı bir şekilde farklıdır. Yani deney ve kontrol grubundaki deneklerin başarıları denemelere bağlı olarak farklılık göstermektedir. Başka bir anlatımla uygulanan deneysel işlemin bir sonucu olarak başarı puanları değişmektedir.

Şekil 1. Öğrencilerin Öntest- Sontest Başarı Puanları Grafiği (Ortalama Puanlardaki DeğişimGrup Eksenli)

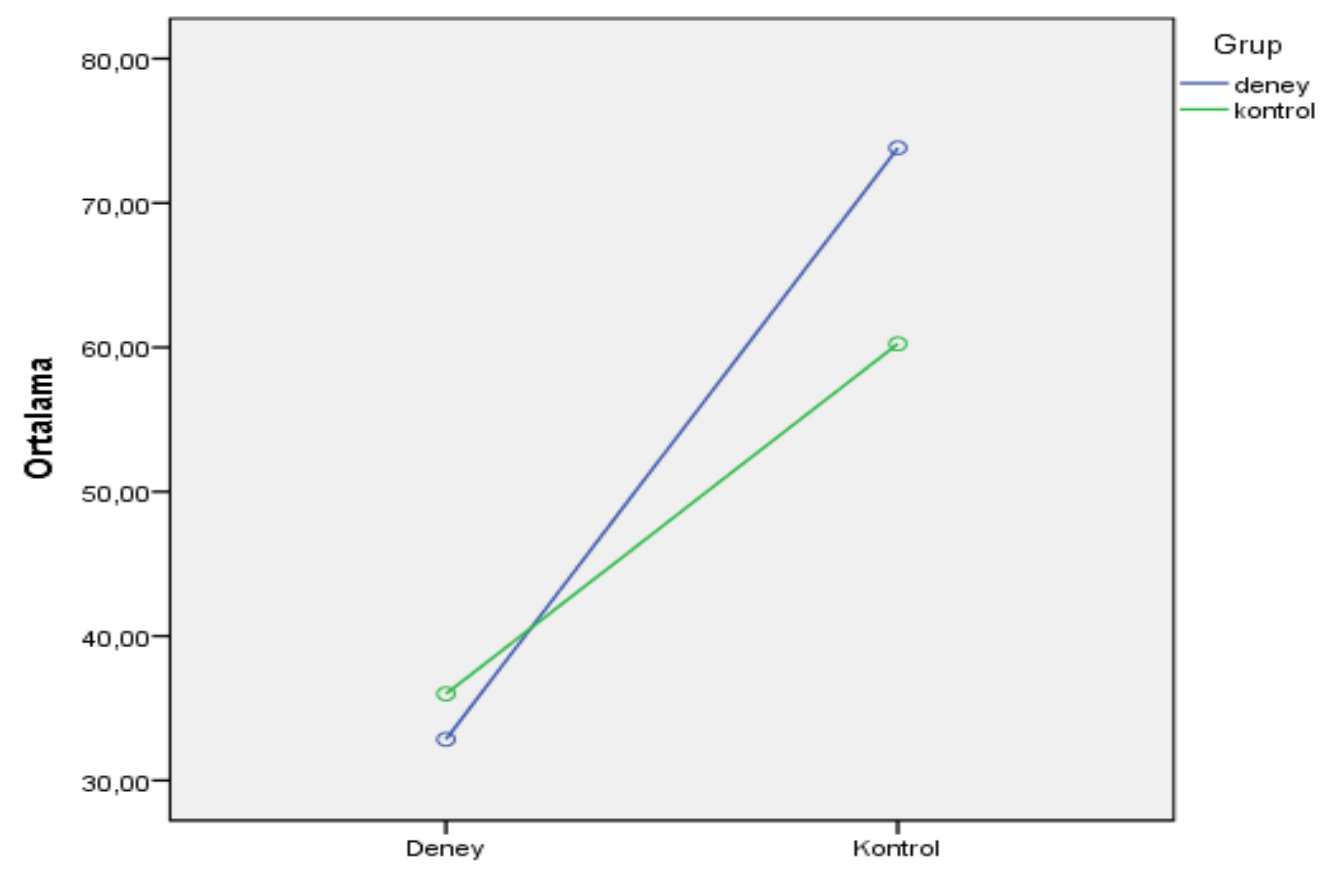

Şekil 1 incelendiğinde iki doğrunun kesiştiği iki uçtan birinde birbirlerine oldukça yaklaşmaları, deney ve kontrol grubunun deneklerinin deney öncesi ve sonrası başarı puanlarındaki değişmelerin farklı olabileceği şeklinde yorumlanabilir.

\section{İkinci Alt Probleme Ait Bulgular}

Araştırmanın ikinci alt problemi ise "Hikâye destekli uygulamalar sonucunda öğrencilerin zihinlerinde ilkçağ uygarlıklarına ilişkin oluşan farkındalık düzeyleri nelerdir?” şeklindedir. Bu soruya yanıt bulmak için hikâye destekli uygulamalar sonucunda her bir hikâye için deney grubuna hikâyelere ilişkin çeşitli görüş aldırıcı soruların yer aldığı öğrenci çalışma 
kâğıtları dağıtılmış; öğrencilere okunan hikâyelerin onlar için anlamlı öğrenmeler sağlayıp sağlamadığı 5. Sınıf "Kültür ve Miras Ünitesi kazanımı olan" Somut kalıntılarından yola çıkarak Anadolu ve Mezopotamya uygarlıklarının insanlık tarihine önemli katkılarını fark eder" kazanımından yola çıkılarak sorulmuştur.

İlkçağ uygarlıklarıyla ilgili hikâyelerin öğrencilerin zihinlerinde anlamlı bir öğrenme sağlayıp sağlamadığına ilişkin bulgular temalar halinde Tablo 6'da verilmiştir.

Tablo 6

İlkçağ Uygarlıklarıyla illgili Hikâyelerin Öğrencilerin Zihinlerinde Anlamlı Bir Öğrenme Sağlayıp Sağlamadığına Dair Bulgular

\begin{tabular}{|c|c|c|}
\hline Tema & Katılımcılar & $f$ \\
\hline Evet, etkili ve anlamlı oldu & $\begin{array}{l}\text { K1, K2, K3, K4, K5, K6, K7, K8,K10, } \\
\text { K11, K13, K14, K15, K17, K18, K19, } \\
\text { K20, K21, K22, K23, K24, K25, K26, } \\
\text { K27, K28, K29, K30, K31, K32, K33 }\end{array}$ & 30 \\
\hline \multicolumn{3}{|l|}{ Gerekçeler } \\
\hline Dikkat çekici olma & $\mathrm{K} 1, \mathrm{~K} 3, \mathrm{~K} 5, \mathrm{~K} 13, \mathrm{~K} 17, \mathrm{~K} 23, \mathrm{~K} 27$ & 7 \\
\hline Sıkıcı olmama & $\mathrm{K} 4, \mathrm{~K} 20, \mathrm{~K} 24, \mathrm{~K} 28$ & 4 \\
\hline Empati kurmayı sağlama & $\begin{array}{l}\mathrm{K} 3, \mathrm{~K} 7, \mathrm{~K} 10, \mathrm{~K} 11, \mathrm{~K} 14, \mathrm{~K} 15, \mathrm{~K} 17, \mathrm{~K} 18, \\
\mathrm{~K} 20, \mathrm{~K} 22, \mathrm{~K} 24, \mathrm{~K} 26, \mathrm{~K} 29, \mathrm{~K} 30, \mathrm{~K} 32\end{array}$ & 15 \\
\hline Eğlenceli olma & $\begin{array}{l}\text { K1, K2, K6, K10, K18, K19, K21, K28, } \\
\text { K29 }\end{array}$ & 9 \\
\hline Hayal kurma becerisini arttırma & K4, K8, K20, K27, K33 & 5 \\
\hline Gözünde canlandırabilme & $\mathrm{K} 4, \mathrm{~K} 8, \mathrm{~K} 18, \mathrm{~K} 20, \mathrm{~K} 25, \mathrm{~K} 28, \mathrm{~K} 31, \mathrm{~K} 33$ & 8 \\
\hline Kalıcı olma & $\begin{array}{l}\mathrm{K} 1, \mathrm{~K} 3, \mathrm{~K} 4, \mathrm{~K} 5, \mathrm{~K} 8, \mathrm{~K} 13, \mathrm{~K} 18, \mathrm{~K} 19, \mathrm{~K} 20, \\
\mathrm{~K} 21, \mathrm{~K} 22, \mathrm{~K} 24, \mathrm{~K} 29\end{array}$ & 13 \\
\hline Daha çok bilgi verme & K11, K14, K31 & 3 \\
\hline Anlamlı olma & $\mathrm{K} 19, \mathrm{~K} 25$ & 2 \\
\hline $\begin{array}{l}\text { Hayır, etkili ve anlamlı olmadı } \\
\text { Gerekceler }\end{array}$ & $\mathrm{K} 9, \mathrm{~K} 12, \mathrm{~K} 16$ & 3 \\
\hline Hikâyeleri saçma bulma & K9 & 1 \\
\hline Karışık bulma & $\mathrm{K} 9, \mathrm{~K} 12, \mathrm{~K} 16$ & 3 \\
\hline Dikkat çekici bulmama & K12 & 1 \\
\hline $\begin{array}{l}\text { Ders kitabından işleseydik daha iyi } \\
\text { olurdu }\end{array}$ & $\mathrm{K} 12, \mathrm{~K} 16$ & 2 \\
\hline Kötü örnek olması & K12 & 1 \\
\hline
\end{tabular}

Yukarıda yer alan tabloda görüldüğü üzere 30 öğrenci, okudukları hikâyenin öğrenme süreçleri üzerinde etkili ve verimli olduğunu ifade ederken, 3 öğrenci hikâye destekli 
öğrenmenin etkili olmadığını ifade etmiştir. Öğrenme süreçleri üzerinde hikayelerin etkili olduğunu ifade eden öğrencilerin gerekçeleri, bu hikayelerin dikkat çekici olup, sıkıcı olmaması, eğlenceli bir öğrenme ortamı sunması, hikayelerin hayal kurma ve empati becerisini geliştirmesi, öğrencilerin zihinlerinde canlandırabilmelerini sağlaması, kalıcı olması, daha çok bilgi vermesi ve anlamlı olması şeklinde özetlenebilir.

Okudukları ilkçağ uygarlıklarına ait hikâyelerin öğrenme süreçleri üzerinde etkili ve verimli olduğunu ifade eden öğrencilerden K1: "Evet etkili oldu, çünkü örneğin Sümerlere ait o kadar çok güzel şey vardı ki dikkatimi çekti, aklımda kaldı." diyerek hikâyelerin farklı bilgiler sunduğunu ve kalıc öğrenmeler sağladığını ifade etmiştir. K3 kodlu öğrenci ise, "Hikâyeler çocukların akıllarında daha çok kalır. Hikâye şeklinde olduğu için çocukların dikkatini çeker ve aklımızda kalmasını sağlar." diyerekhikâye destekli öğrenmelerin çocuklar için daha uygun olduğunu vurgulamıştır. K11 ise: "Bana çok yardımcı oldu. Sümerlileri daha iyi anladım. Sanki Sümerlerin zamanında olduğumu hissettim." diyerek tarihsel bir zaman dilimiyle duygudaşlık hissi geliştirebildiğini, kahramanlarla empati kurabildiğini ifade etmiştir. Yine K20 kodlu öğrenci “Hikâyeler daha çok akılda kalıcı ve insan kendini Abebe'nin yerine koyup öyle düşünüyor ve hiç sıkıcı olmuyor. Ben resmen Abebe'nin yerindeymişim gibi hissediyorum. Hikâyelerde olaylar insanın gözünde canlandıracak şekilde anlatılmış. Hikâyede olayların, renklerin, şekillerin hangi şekilde olduğunu söylediğinden insanın içi kaynaşıyor, her şeyi anlatıyor." diyerek, hikâyelerin hayal kurma becerisini artırdığını ifade etmiştir.

K24 kodlu öğrenci "Asur Tüccarları" isimli hikâyeye atıfta bulunup, bu hikâyenin anlamlı ve kalıcı öğrenme imkânı sağladığını ifade ederek: "Faydalı oldu. Eğer bunları yazarak ve bilgiler ile öğrenseydik daha sıkıcı olurdu. Ben sanki o hikâyedeki kişiler gibiydim. Diğer şekilde sıkıcı olurdu ve az şey öğrenirdim." demiştir. K29 Kodlu öğrenci ise: "Evet düşünüyorum. Çünkü oranın güzelliklerini anlatmış. Bu da etkili, eğlenceli olmuş. Daha çok aklımızda kalır." demiştir. K19 kodlu öğrenci ise "Babilin Asma Bahçeleri" için: "Kalıcı oldu ve anlamlı oldu. Daha çok hatırlarım." demiştir.

K24 kodlu öğrenci "Hitit Ülkesi" isimli hikâye için: "Evet, normal ders kitabından işleseydik bu kadar etkili olmaz, aklımızdan çıkardı." demiştir. K18 kodlu öğrenci "Frig Kralı Gordios" isimli hikâyeye vurgu yaparak "Evet çok güzel ve eğlenceli olarak öğrenmemi sağladı." demiştir. K27 kodlu öğrenci ise "Evet, nedense anlamama yardımcı olacak şekilde anlatılmış. Hayalini kurdum, Gözümde canlandı." demiştir. K33 kodlu öğrenci "Altın Ülkesi 
Lidya" isimli hikâye için: "Evet bu sayede gözümde iyi canlandı. Bu da benim dikkatimi çekti. Gözümde her şey canlandı. Bu sayede çok iyi anlamamı sağladı." demiştir. K13: "Bana birçok ders verdi. Ne yapmam gerektiğini öğrendim." demiştir. "Iyonya Şehirleri” isimli hikâyeye değinen K4 kodlu öğrenci: “Evet anlayabileceğim bir şekilde anlatılmış. Bu da benim daha iyi anlamamı sağlıyor. Gözümde canlandı." diyerek hikâyelerin olayları somutlaştırdığını, hayal gücünü geliştirdiğini vurgulamıştır. "Yüksek Dağlar Ülkesi Urartu" hikâyesiyle ilgili K30 kodlu öğrenci: "Dağlarda yaşayan Urartuları tanımış oldum. Ülkeleri soğuk olmalı.” demiştir.

Okunan hikâyelerle ilgili olarak olumsuz görüş belirten ve bu hikâyelerin akılda kalıcı olmadığını vurgulayan öğrenciler için hikâyeler anlamsız, saçma ve karmaşık, kötü örnek oluyor şeklinde nitelendirilmiştir. Bir öğrenci ise konuları ders kitabından işlemenin daha yerinde olacağını ifade etmiştir. Farklı hikâyeler için cevap veren öğrencilerden K9: “Asur Tüccarları" isimli hikâyeye vurgu yaparak "Kalıcı ve anlamlı olduğunu düşünmüyorum. Çünkü karışık bir hikâye ve akılda kalacağını düşünmüyorum. Biraz saçma buldum, beğenmedim." diyerek, hikâyenin kendisi için zor olduğunu ifade etmiştir. K12 kodlu öğrenci ise benzer şekilde "Hayır düşünmüyorum, çünkü çok karmaşık hikâyeler, dikkatimi çekmedi." demiştir. K16 kodlu öğrenci ise: "Bence fazla akılda kalmadı. Ders kitabından işlesek daha iyi olur." demiştir. K12 kodlu öğrenci: "Bence değil, çünkü dikkatimi çekmedi." demiştir. K16 kodlu öğrenci: "Bence fazla akılda kalmadı. Ders kitabından işlesek daha iyi olur." demiştir. K12 kodlu öğrenci: "Ben yardımcı olduğunu düşünmüyorum. Çünkü ayrı ayrı devlet oldukları için bu bize kötü örnek oluyor." demiştir.

\section{Sonuç}

Araştırma kapsamında elde edilen bulgular hikâye destekli öğretim yönteminin öğrenci başarısını artırdığını ortaya koyduğu söylenebilir. Deney grubuna ait son test başarı puanının kontrol grubuna ait son test başarı puan ortalamasından yüksek olması hikâye destekli öğretimin öğrencilerin akademik başarısı üzerinde olumlu bir etkide bulunduğunu gösterebilir. Bu sonuçlar edebi ürün kullanılarak gerçekleştirilen öğretim yöntemlerinin verimliliğine dönük yapılan bazı çalışmaların (Akengin ve Tuncel, 2003; Demir, 2011; Keskin, 2008; Sidekli, Tangülü ve Yangın, 2013; Şimşek, 2000; Şimşek, 2004) sonuçları ile benzerlik göstermektedir.

Araştırma kapsamında tasarlanan hikâyeler aracılığıyla ilkçağ uygarlıklarına ait özellikler edebi bir üslupla öğrencilere aktarılmıştır. Bilgi aktarımı olarak tasarlanan tarihsel 
anlatıya kıyasla, hikâyeler ve insan yaşamından kesitlerin sunulduğu tarihi hikâyelerin daha etkili ve daha kalıcı olduğu düşünülebilir. Uygulamalar esnasında öğrencilerin yer, mekân, zaman ve şahıslarla kendi yaşamları arasında özdeşim kurması, benzerlik ve farklılıkları keşfedebilmesi öğrenmelerin yapılandırmacı bir temelde daha kalıcı olmasını sağlayabilmektedir. Araştırma sonucunda elde edilen bulgular, tarihsel hikâyeye yönelik farklı araştırmacılar (Altunay Şam, 2011; İncegül, 2010; Koçak 2004; Şimşek, 2004; Şimşek, 2006) tarafından yapılan çalışmalarla benzerlik göstermektedir. Tarihsel hikâyelerin yaşanmış bir örnek olay olarak öğrenciye aktarılabileceğini söyleyen Koçak (2004), tarihsel hikâyelerin, sorular aracılığı ile öğrencilerin yorum yapabilmesine imkân sağlayabileceğini, bu sayede öğrencilerin öğrenme süreçlerine faal bir şekilde katılabileceğini ifade etmektedir. Bu bağlamda hikâye anlatım yöntemi, sosyal bilgiler programında yer alan tarih konularının yüzeysel olarak ele alınmasını da önleyecektir. Illkçağ Uygarlıkları gibi tarihsel olarak uzak bir zaman dilimindeki yaşantıların hikâyelerle öğrencilere aktarılması sonucunda öğrenmelerin daha ilgi çekici ve daha kalıcı olabileceği düşünülmektedir.

Uygulamalar esnasında edebi bir dille ifade edilen tarihsel bilgilerin öğrenciler tarafından ilgiyle takip edildiği, hikâyelerde yer alan karakterleri ilgiyle ve büyük merak duygusuyla takip ettikleri görülmüştür. Tarihsel bilgileri savaş, barış, anlaşma gibi ezber bilgiler olarak kavramakta zorlanan öğrencilerin, hikâyelerdeki kurgusal anlatıyla bilgileri daha büyük bir ilgiyle ve alakayla takip ettiği görülmektedir. Ortaya çıkan bu sonuçlar alan yazında, (Akkuş, 2007; Ata, 2014; Demir ve Akengin, 2012; Dilek ve Soğucaklı Yapıcı, 2005; Kaymakçı, 2013; Oruç, 2009; Öztürk ve Otluoğlu, 2002; Öztürk, Keskin ve Otluoğlu, 2014; Şimşek, 2014) tarafından yapılan çalışmalarla benzerlikler göstermektedir. Bu doğrultuda araştırmadan elde edilen sonuçlara göre, sosyal bilgiler dersinde hikâyelerin bir öğretim materyali olarak kullanıldığı yöntemin etkili olduğu söylenebilir. Bu anlamda İlkçağ Uygarlıklarına ait konuların öğretiminde hikâye tekniğinin aktif olarak kullanılması, öğrencilerin ilgili zaman dilimine ait yaşam tarzıyla kendi yaşamları arasında bağ kurmalarına, tarihsel empati geliştirebilmelerine ve öğrendikleri bilgileri yapılandırmalarına imkân sağlayabilir.

Araştırmadan elde edilen sonuçlara dayanarak şu önerilerde bulunulabilir:

- Sosyal bilgiler dersinin öğretiminde, diğer ünitelerin de içeriğine uygun olarak farklı hikâyeler kullanılabilir. 
- Öğretmenler tarafından öğrencilerin derse aktif katılımlarını sağlamak için ünitelerin içeriğine uygun birtakım hikâyeleri, öğrencilerin kendi yaratıcılıklarını da kullanarak tasarlamaları istenebilir.

\section{Kaynakça}

Altunay Şam, E. (2011). "Şu Çılgın Türkler" romanının kurutuluş savaşı bilgisini öğrenmeye etkisi. Journal of New World Sciences Academy, s. 2555-2568.

Akengin, H., ve Tuncel, G. (2003). Sosyal bilgiler öğretiminde bir yönem olarak empatinin etkililiği. I. Sosyal Bilimler Eğitimi Kongresi. Dokuz Eylül Üniversitesi Buca Eğitim Fakültesi, İzmir.

Akkuş, Z. (2007). Tarih öğretiminde edebi ürünlerin kullanımının öğrenci başarısına etkisi (Yayınlamış Doktora Tezi), Atatürk Üniversitesi, Sosyal Bilimler Enstitüsü, Erzurum.

Ata, B. (2001). Çanakkale Savaşlarını Nasıl Öğreteceğiz? Türk Yurdu, 164, 23-29.

Ata, B. (2014). Türkiye'de tercüme faaliyetleri içinde eğitim klasiklerinin yeri ve bu eserlerin sosyal bilgiler eğitimine katıkıları. B. Ata ve İ. Bağcı (Edt), Sosyal Bilgiler Eğitimi Açııından Eğitim Klasikleri incelemeleri (s. 1-20). Ankara: Pegem.

Büyüköztürk, Ş., Kıllı̧ Çakmak, E., Akgün, Ö. E., Karadeniz, Ş., ve Demirel, F. (2013). Bilimsel araştırma yöntemleri. Ankara: Pegem.

Çencen, N. ve Berk, N. (2014). Ortaöğretim TC Inkılâp Tarihi ve Atatürkçülük dersinde "şiir kullanımına" ilişkin öğretmen görüşleri. TurkishHistoryEducationJournal, 3(1), s. 1-23.

Dilek, D., ve Soğucaklı Yapıcı, G. (2005). Öykülerle tarih öğretimi yaklaşmı. Dokuz Eylül Üniversitesi Buca Eğitim Fakültesi Dergisi S. (18), s. 115-130.

Demir, S. B. (2011). Sosyal bilgiler öğretim proğramına göre düzenlenmiş hikayelerin etkililiği (Yayınlanmış Doktora Tezi). Marmara Üniversitesi, Eğitim Bilimleri Ensitüsü, İstanbul.

Demir, S. B., ve Akengin, H. (2012). Hikayelerle Sosyal Bilgiler Öğretimi. Ankara: Pegem. 
Dolmaz, M. (2017). Sosyal bilgiler öğretiminde tarihsel roman kullanımının yaratıcı yazmabecerilerine etkisi. (Yayınlanmış Dotora Tezi). Türkiye: Erzincan Üniversitesi SosyalBilimler Enstitüsü, Erzincan.

Gülüm, K. ve Ulusoy, K. (2008). Sosyal bilgiler dersinde göç konusunun işlenişinde halktürkülerinin kullanılması (örnek bir çalışma). Elektronik Sosyal Bilimler Dergisi, 7(26),s. 112-127.

Jordan, J. (1992). Effects of a literature-based approach to history on sixth graders' achievement and attitudes. ERIC Document Reproduction Service No. ED351251)

Karasar, N. (2002). Bilimsel araştırma yöntemi. Ankara: Nobel.

Kaymakçı, S. (2013). Sosyal bilgiler ders kitaplarında sözlü ve yazılı edebi türlerin kullanılma durumu. Dicle Üniversitesi Ziya Gökalp Eğitim Fakültesi Dergisi, 20, s.230-255.

Keskin, Y. (2008). Türkiye'de sosyal bilgiler öğretim programlarında değerler eğitimi: Tarihsel gelişim, 1998 ve 2004 programlarının etkililiğinin araştııılması (Yayınlanmış Doktora Tezi). Türkiye: Marmara Üniversitesi Eğitim Bilimleri Enstitüsü, İstanbul.

Koçak, A. (2004). ilköğretim sosyal bilgiler dersinde osmanlı devleti'nin XIX. yüzyıllarının öğretiminde hatıra ve hikayelerin kullanılması. (Yayınlanmış Yüksek Lisans Tezi). Selçuk Üniverisitesi Sosyal Bilimler Enstitüsü, Konya.

Köksal, H. (2007). İlkçağda vatandaşlık eğitimi olarak tarih öğretimi. Kastamonu Eğitim Dergisi, S. 15 , s. $271-278$.

Köstüklü, N. (2006). Sosyal bilimler ve tarih öğretimi. Konya: Selçuk Üniversitesi.

MEB. (2018). Sosyal Bilgiler Dersi Öğretim Programı. Sosyal Bilgiler Dersi Öğretim Program (ilkokul ve Ortaokul 4, 5, 6, 7. Sınıflar). Ankara: Talim Terbiye Kurulu.

Mcgown, T., ve Guzetti, B. (2004). Edebiyat temelli sosyal bilgiler öğretimi (Çev. Doğanay A.). Çukurova Ünivesitesi Sosyal Bilgiler Dergisi, s. 35-44.

Oruç, Ş. ( 2009). Sosyal bilgiler 6. sınıf ders kitaplarında edebi ürünler. TSA, s. 9-24.

Öztaşkın, Ö., ve Üngör, i̇. (2013). Sosyal bilgiler ders kitaplarında eski çağ tarihi konusu ve bilincinin bilimsel içerik bakımından değerlendirilmesi. e-international Journal of Educational Research, s. 1-26. 
Öztürk, C., ve Otluoğlu, R. (2002). Sosyal bilgiler öğretiminde yazılı edebiyat ürünlerini ders aracı olarak kullanmanın duyuşsal davranış özelliklerini kazanmaya etkisi. Atatürk Eğitim Fakültesi Eğitim Bilimleri Dergisi, s. 173-182.

Öztürk, C., Keskin, S. C., ve Otluoğlu, R. (2014). Sosyal bilgiler öğretiminde edebi ürünler ve yazılı materyaller. Ankara: Pegem.

Öztürk, i. H. (2011). Tarih öğretiminde anakronizm sorunu: Sosyal bilgiler ve tarih ders kitaplarındaki kurgusal metinler üzerine bir inceleme. Sosyal Bilgiler Eğitimi Araştırmaları Dergisi, s. 35-58.

Savage, Mrsha, K., ve Svage, T. V. (1993). Children's literature in middle school social studies. The Social Studies, S. 82(1), s. 32-36.

Sidekli, S., Tangülü, Z., ve Yangın, S. (2013). Sosyal bilgiler öğretimi: Bana bir hikaye anlatır mısın? Uşak Üniversitesi Sosyal Bilimler Dergisi, S.(6/4), s. 311-323.

Şimşek, A. (2000). Ilköğretim sosyal bilgiler öğretiminde hikaye anlatım yönteminin kullanımı (Yayınlanmış Yüksek Lisans Tezi). Gazi Üniversitesi, Sosyal Bilimler Ensitüsü, Ankara.

Şimşek, A. (2004). Illköğretim okulu sosyal bilgiler dersi tarih konularının öğretiminde hikaye anlatım yönteminin etkililiği. Türk Eğitim Bilimleri Dergisi, s. 495-509.

Şimşek, A. (2006). Illköğretim sosyal bilgiler dersinde tarihsel hikâyeye yönelik olarak öğrenci görüşleri. Gazi Eğitim Fakültesi Dergisi, S. (26), s. 187-202.

Şimşek, A. (2009). Sosyal bilgiler derslerinde bir öğretim materyali olarak edebi ürünler. M. Safran (Edt.), Sosyal Bilgiler Öğretimi (s. 390-409). Ankara: Pegem.

Şimşek, A. (2011). Geçmişin nesnesini arayan bilim arkeoloji: Türiye'de tarih öğretimindeki durumu. Turkish Studies - International Periodical For The Languages, Literature and History of Turkish or Turkic, s. 919-934.

Şimşek, A. (2014). Sosyal bilgiler öğretiminde bir öğretim materyali olarak edebi ürünler, Ankara: Pegem.

Taşkın, A. (2016). Cumhruriyet döneminde ilkokul tarih/sosyal bilgiler ders kitaplarında eskiçağ tarihinin öğretiminin incelenmesi. (Yayınlanmış Yüksek Lisans Tezi). Sakarya Üniversitesi Eğitim Bilimleri Enstitüsü, Sakarya. 
Turgut, M.F. (1992). Eğitimde ölçme ve değerlendirme metotları, Ankara: Saydam.

Yasa, Ş. ve Pamuk, A. (2017). Türk denizcilik tarihinin öğretiminde tarihsel romanlarınkullanımının tarihsel düşünme becerisine etkisinin incelenmesi: Bir eylemaraştırması. Marmara Üniversitesi Atatürk Eğitim Fakültesi Eğitim BilimleriDergisi, 49(49), s. 203-222.

Yıldırım, A., ve Şimşek, H. (2005). Sosyal bilimlerde nitel araştırma yöntemleri. Ankara: Seçkin.

Yılmaz, A. A. (2011). Tarih Öğretmenlerinin eskiçağ tarihi ve eski türk tarihi öğretiminde karşılaştıkları sorunlar ve çözüm önerileri. e-Journal of New World Sciences Academy, s. 2148- 2156. 